\title{
Antioxidant properties of BJRI vegetable mesta-1 (Hibiscus sabdariffa L.)
}

\author{
Md. Abul Fazal Mollah, Md. Zablul Tareq, Kazi Khayrul Bashar*, A. B. M. Zahidul Hoque, Md. Meftahul \\ Karim \& Md. Zahid Al Rafiq \\ Bangladesh Jute Research Institute, Manik Mia Avenue, Dhaka 1207, Bangladesh \\ *Email: kazi.khayrulbashar@gmail.com
}

\section{ARTICLE HISTORY}

Received: 24 November 2019

Accepted: 15 December 2019

Published: 01 April 2020

\section{KEYWORDS}

Roselle; BJRI vegetable mesta-1; calyx; antioxidant properties

\section{ABSTRACT}

Roselle or Mesta (Hibiscus sabdariffa) is one of the plants whose plant parts are used to prepare juices. The Roselle calyx is considered as a good source of antioxidants. But the antioxidant properties of BJRI (Bangladesh Jute Research Institute) released Roselle vegetable variety, BJRI vegetable mesta-1, is not quantified yet. With the objective of making this vegetable more popular among the consumers, an experiment was conducted at the Jute Agriculture Experimental Station, Bangladesh Jute Research Institute, Jagir, Manikganj to find out the antioxidant properties of BJRI vegetable mesta-1. Total four antioxidant components eg., total phenol content, total flavonoid content, proanthocyanidin content, anthocyanin content and three antioxidant activities eg., DPPH (1,1-diphenyl-2-picrylhydrazyl) radical scavenging, (FRAP) ferric ion reducing antioxidant power, $\mathrm{H}_{2} \mathrm{O}_{2}$ (hydrogen peroxide), radical scavenging were measured from the calyx sample of BJRI vegetable mesta-1. Among the four antioxidant components, total flavonoid contents (959.53 mg $100 \mathrm{~g}^{-1}$ ) posses the highest position and anothocyanine contents $\left(0.17 \mathrm{mg} 100 \mathrm{~g}^{-1}\right)$ were in the lowest position. FRAP activities were highest among the antioxidant activities of the calyx of our studied vegetable mesta. Our findings represented the quantity of antioxidant contents of the calyx of BJRI vegetable mesta-1 which justify its uses as natural antioxidants. Thus, Roselle calyx may act as an alternative source of antioxidant rich natural herbal tea.

\section{Introduction}

Roselle (Hibiscus sabdariffa L.) of Family Malvaceae is popularly known as 'mesta' or 'chukur' in Indian subcontinent including Bangladesh $(1,2)$. It is widely cultivated crop in tropical countries, Sudan, Egypt, Mali, Nigeria, India, Indonesia, Malaysia, Brazil, Australia and Mexico. Roselle leaves and flower calyx are consumed as vegetable (3). Roselle flower has a solid fleshy calyx at the base, $1 \mathrm{~cm}$ to $2 \mathrm{~cm}$ wide, enlarging to $3 \mathrm{~cm}$ to $3.5 \mathrm{~cm}$. The calyx (red and dark red) are used to extract juice for fresh drink and the leaves (green colored calyx) are used as vegetables (4). Roselle calyx is sweet in taste and should be picked 10 to 15 days after they lose its blooms, other wise it will taste more tart $(5,6)$.

In many countries, this plant is primarily cultivated for bast fiber from the stem. The fiber is used as a substitute for jute in making burlap. The red calyx of the plant are used as food colorings and dyes
(7). The food and beverage manufacturers and pharmaceutical concerns have considered Roselle as a herbal medicine and an alternate source of colorant for synthetic dyes (8). The most important use of Roselle calyx as Roselle tea that regulates blood pressure, cholesterol and prevents cardiovascular diseases. Roselle tea acts as an anti-inflammatory agent, assists in digestion and reduces the risk of cancer (8). Roselle calyx tea is also rich in vitamin C, minerals and antioxidants. It has distinct maroon color along with sweet and tart flavor similar to that of cranberries (3). It can be enjoyed both hot and cold depending on consumer's preferences (8).

It has been observed that it has potential use as a medicine for curing diseases in aquatic organisms as roselle extract significantly elevated levels of lactate dehydrogenase (LDH), glutamate oxalate transaminase (GOT), glutamate pyruvate transaminase (GPT) and malondialdehyde (MDA) (9). It significantly reduces levels of superoxide dismutase

(c) Mollah et al. (2020). This is an open-access article distributed under the terms of the Creative Commons Attribution License, which permits unrestricted use, distribution, and reproduction in any medium, provided the original author and source are credited (https://creativecommons.org/licenses/by/4.0/).

To cite this article: Mollah MAF, Tareq MZ, Bashar KK, Hoque BMZ, Karim MM, Rafiq MZA. Antioxidant properties of BJRI vegetable mesta-1 (Hibiscus sabdariffa L.). Plant Science Today. 2020;7(2):154-156. https://doi.org/10.14719/pst.2020.7.2.664 
(SOD) and glutathione peroxidase (GSH-Px). Limited research work has been done on its antioxidant properties of Roselle calyx. But unfortunately, there is no information on the antioxidant properties of BJRI released Roselle variety named as BJRI vegetable mesta-1. This vegetable Roselle variety is not gaining popularity with its vegetable properties only. Therefore, Roselle calyx tea bearing considerable amount of antioxidant properties may improve the acceptance of BJRI vegetable mesta-1 to the consumer. Considering this fact an effort was made to quantify the antioxidant properties of the calyx of BJRI vegetable mesta- 1 .

\section{Materials and Methods}

\section{Plant materials and growth conditions}

This experiment was conducted at the Jute Agriculture Experimental Station, Bangladesh Jute Research Institute, Manikganj, Bangladesh from August to December, 2018 to quantify the antioxidant properties of BJRI vegetable mesta-1. The altitude of the experimental field was $4 \mathrm{~m}$ in the old Brahmaputra-Jamuna flood plain (Agro-ecological Zone-8) with a silt loam soil. Seeds were collected from Jute Agriculture Experimental Station, BJRI, Jagir, Manikganj. The crop was sown on $10^{\text {th }}$ August, 2018 and calyces were harvested at $10^{\text {th }}$ December, 2018.

The unit plot size was $4 \times 2 \mathrm{~m}$, with line spacing of $50 \mathrm{~cm}$, plant to plant spacing was $8-10 \mathrm{~cm}$. seeds were sown in line sowing method. The experimental field was medium high land belonging to old Brahmaputra-Jamuna flood plain having silt loam soil with $\mathrm{pH}$ 6.7. The soil contained $1.6 \%$ organic matter, $0.08 \%$ total nitrogen, $12.31 \mathrm{ppm}$ available phosphorus, 0.21 meq. Potassium $100 \mathrm{~g}^{-1}$ and 20.93 ppm available sulfur. Land was prepared by cross ploughing with laddering. Soil was fertilized with urea, triple super phosphate, muriate of potash, gypsum and zinc sulphate @ 200 kg, 25 kg, 30 kg, 45 $\mathrm{kg}$ and $12 \mathrm{~kg} \mathrm{ha}^{-1}$, respectively. Half of urea and full amount of other fertilizers were applied as basal dose during final land preparation. Remaining amount of urea was top dressed at 20 days after sowing. All intercultural operations were done when necessary. The experiment was designed by the Randomized Complete Block Design (RCBD) with three replications.

\section{Chemical analysis}

Calyx samples were collected from 120 days old plants. Antioxidant compounds including total flavonoid contents, total phenolic contents, proanthocyanidin content, DPPH radical scavenging, ferric ion reducing antioxidant power and $\mathrm{H}_{2} \mathrm{O}_{2}$ radical scavenging (Unit: \% inhibition) were analyzed by the method of Goufo and Trindade (10) at the Department of Food Processing and Preservation, Hajee Mohammad Danesh Science and Technology University, Dinajpur-5200, Bangladesh.

\section{Statistical analysis}

All analyses were run in triplicate and the results were expressed as means \pm standard deviation (SD).
Statistical analyses were done by using SPSS statistical package (SPSS 22.0 for Windows; SPSS, Chicago, IL, USA).

\section{Results and Discussion}

\section{Antioxidant contents in the calyx}

It has been seen that the total phenol contents were $521.46 \mathrm{mg} 100 \mathrm{~g}^{-1}$ in the calyx of BJRI vegetable mesta-1 (Table 1A). There are reports on the total phenolic contents of Roselle extracts ranged from 108 to $546 \mu \mathrm{g} \mathrm{g}^{-1}$ (12) 582 to $606 \mu \mathrm{g} \mathrm{g}^{-1}$ (13) respectively. The results of various studies revealed that phenolic contents of Roselle calyx are less variable among various genotypes of Roselle.

Flavonoids act as anti-cancerous agents (3). Thus, required flavonoid intake may reduce the risk of cancer in human (14). There was $959.53 \mathrm{mg} 100 \mathrm{~g}^{-1}$ flavonoid in the calyx of BJRI vegetable mesta-1 (Table 1A) which agrees with the earlier findings (15). They reported flavonoid contents ranging from 9.31$404.40 \mu \mathrm{g} \mathrm{g} \mathrm{g}^{-1}$. Thus, our tested variety has higher flavonoid contents.

Anthocyanin improves overall visual acuity, blood flow, blood pressure, decreases cholesterol levels and fights against oxidative stress $(16,17)$. In the present case, the total anthocyanins were $0.17 \mathrm{mg}$ $100 \mathrm{~g}^{-1}$ (Table 1A). Similar results were also reported $(18,19)$. The present findings differ from our earlier work (15). Different extraction procedures (modified protocol) and genotypes may account for this variation (10, 20). Proanthocyanidins have much stronger antioxidant activities than vitamin $\mathrm{C}$ or vitamin $\mathrm{E}$ (21). The total $284.27 \mathrm{mg} 100 \mathrm{~g}^{-1}$ proanthocyanidin contents were measured in the calyx of BJRI vegetable mesta-1 (Table 1A), which agree with a previous record (10).

Table 1. Antioxidants and Antioxidant activities of BJRI vegetable mesta-1 calyx samples.

\begin{tabular}{|c|c|}
\hline Name of the components & $\begin{array}{c}\text { Average Contents } \\
\left(\mathrm{mg} 100 \mathrm{~g}^{-1}\right)\end{array}$ \\
\hline \multicolumn{2}{|l|}{ A. Antioxidant components } \\
\hline Total phenol contents & $521.46 \pm 15.26$ \\
\hline Total flavonoid contents & $959.53 \pm 13.50$ \\
\hline Proanthocyanidin contents & $284.27 \pm 0$ \\
\hline Anthocyanin contents & $0.17 \pm 0.01$ \\
\hline \multicolumn{2}{|l|}{ B. Antioxidant activities } \\
\hline DPPH radical scavenging & $5039.16 \pm 15.63$ \\
\hline Ferric ion reducing antioxidant power (FRAP) & $29060.83 \pm 693.06$ \\
\hline $\mathrm{H}_{2} \mathrm{O}_{2}$ Radical Scavenging (Unit: \% inhibition) & $1358.76 \pm 136.21$ \\
\hline
\end{tabular}

\section{Antioxidant activity of the calyx}

Roselle possessed antioxidant properties that may provide health benefits to people $(22,23)$. The DPPH radical scavenging activity, $\mathrm{H}_{2} \mathrm{O}_{2}$ radical scavenging and ferric ion reduction antioxidant power are presented in the Table 1B. These results clearly indicate the antioxidant activity of the Roselle calyx. The vegetable mesta- 1 contains $5 \mathrm{~g}^{100 \mathrm{~g}^{-1} \mathrm{DPPH}}$ radical scavenging activity (24). In the FRAP assays, the Roselle calyx extract presented good ferric ion

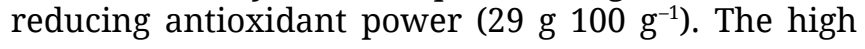


FRAP value of the Roselle calyx aqueous extract could be correlated with the reported presence of chlorogenic acid and its derivatives, which are the main compounds in $H$. sabdariffa extract (25). $\mathrm{H}_{2} \mathrm{O}_{2}$ radical scavenging is an important antioxidant activity of BJRI vegetable mesta-1. Total $1358.76 \mathrm{mg}$ $100 \mathrm{~g}^{-1} \mathrm{H}_{2} \mathrm{O}_{2}$ radical scavenging was measured in the present case. Thus, the Roselle calyx may act as a good source of $\mathrm{H}_{2} \mathrm{O}_{2}$ radical scavenging.

In the present findings, BJRI vegetable mesta-1 has rich antioxidant properties and is a good source of fresh drink. The leaf is consumed as vegetables and calyx can be consider as an alternative herbal tea. Our findings will open a new avenue for producing the calyx powder from Roselle, which would be used as fresh drink in the form of Roselle tea. Thus, our findings will create an opportunity to quantify the nutritional composition of the calyx of BJRI vegetable mesta-1 along with our studied antioxidant properties.

\section{Acknowledgements}

The authors are thankful to the Head, Department of Food Processing and Preservation, Hajee Mohammad Danesh Science and Technology University, Dinajpur5200, Bangladesh for his cordial support.

\section{Author's contribution}

MAFM and MZT Designed and conducted the experiment and analyzed the data; KKB, ABMZH, MMK and MZAR prepared the manuscript.

\section{Competing interest}

Authors do not have any conflict of interest to declare.

\section{References}

1. Halimatul SMN, Amin I, Esa MN, Nawalyah AG, Siti Muskinah, M. Protein quality of Roselle (Hibiscus sabdariffa L.) seeds. ASEAN Food J. 2007;14(2):131-40

2. Ismail A, Ikram EHK, Nazri HSM. Roselle (Hibiscus sabdariffa L.) seeds-nutritional composition, protein quality and health benefits. Food. 2008;2:1-16

3. Islam AKMA, Jamini TS, Islam AKMM Yeasmin S. Roselle: A functional food with high nutritional and medicinal values. Fund Appl Agric. 2016;1(2):44-49

4. Babalola SO. Chemical composition of roselle (leaf). Proc. $24^{\text {th }}$ Annual Conference of the Nigerian Institute of Food Science and Technology, Bauchi, Nigeria. Nov 20-24, 2000; 119-21

5. Cobley LS. An introduction to Botany of Tropical crops. UK: Longman Group; 1976.

6. Crane JC. Roselle- potentially important plant fibre. Econ Bot 1949;3(1):89-103. https://doi.org/10.1007/BF02859509

7. Islam MM. Varietal Advances of Jute, Kenaf and Mesta crops in Bangladesh: A review. Int J Bioorganic Chem. 2019;4(1):24-41. https://doi.org/10.11648/j.ijbc.20190401.15

8. Rao PU. Nutrient composition and biological evaluation of mesta (Hibiscus sabdariffa) seeds. Plant Foods Hum Nutr. 1996; 49(1):27-34. https://doi.org/10.1007/bf01092519
9. Yin G, Cao I, Xu P, Jenny G, Nakao M. Hepatoprotective and antioxidant effects of Hibiscus sabdariffa extract against carbon tetrachloride-induced hepatocyte damage in cyprinus carpio. In vitro Cell Dev Biol Anim. 2011;47:10-15. https://doi.org/10.1007/s11626-010-9359-2

10. Goufo P, Trindade H. Rice antioxidants: phenolic acids, flavonoids, anthocyanins, proanthocyanidins, tocopherols, tocotrienols, c-oryzanol, and phytic acid. Food Sci Nutr. 2014;2(2):75-104. https://doi.org/10.1002/fsn3.86

11. Gomez KA, Gomez AA. Statistical procedures for agricultural research. John Willy and Sons. $2^{\text {nd }}$ ed. New York: A Wiley interscience Publication; 1984

12. Mgaya KB, Remberg SF, Chove BE, Wicklund T. Physiochemical, mineral composition and antioxidant properties of Roselle (Hibiscus sabdariffa L.) extract blended with tropical fruit juices. Afr J Food Agric Nutri Develop. 2014;14:8963-78

13. Luvonga WA, Njoroge MS, Mokokha A, Ngunjiri PW. Chemical characterization of Hibiscus sabdariffa (Roselle) calyces and evaluation of its functional potential in the food industry. Proc. JKUAT Scientific Technological and Industrialization Conference. 2010;631-38. Retrieved from, http://elearning.jkuat.ac.ke/journals/ojs/index.php/jscp/article/ view/745/0

14. Batra P, Sharma AK. Anti-cancer potential of flavonoids: recent trends and future perspectives. 3 Biotech. 2013;3:439-59. https://doi.org/10.1007/s13205-013-0117-5

15. Jamini TS, Islam AKMA, Mohi-ud-Din M, Saikat MMH. Phytochemical composition of calyx extract of roselle (Hibiscus sabdariffa L.) genotypes. J Food Tech Food Chem. 2019;2:102. http://dx.doi.org/10.4314/jafs.v16i1.2

16. Lila MA. Anthocyanins and human health: An in vitro investigative approach. J Biomed Biotechnol. 2004;306-13. http://dx.doi.org/10.1155/S111072430440401X

17. Zhu Y, Bo Y, Wang X, Lu W, Wang X. The effect of anthocyanins on blood pressure: A PRISMA-compliant meta-analysis of randomized clinical trials. Medicine. 2016;95:e3380. http://dx.doi.org/10.1097/MD.0000000000003380

18. Mourtzinos I, Makris DP, Yannakopoulou K, Kalogeropoulos N, Michali I. Thermal stability of anthocyanin extract of Hibiscus sabdariffa L. in the presence of $\beta$-cyclodextrin. J Agric Food Chem. 2008;56:10303-10. https://doi.org/10.1021/jf801389j

19. Juliani HR, Welch $\mathrm{CR}$, Wu Q, Diouf B, Malainy D, Simon JE. Chemistry and quality of hibiscus (Hibiscus sabdariffa) for developing the natural-product industry in Senegal. J Food Sci. 2009;74:113-21. https://doi.org/10.1111/j.1750-3841.2009.01076.x

20. Hughes NM, Smith WK. Attenuation of incident light in Galax urceolata (Diapensiaceae): Concerted influence of adaxial and abaxial anthocyanic layers on photoprotection. Am J Bot 2007;94(5):784-90. https://doi.org/10.3732/ajb.94.5.784

21. Ariga T. The antioxidative function, preventive action on disease and utilization of proanthocyanidins. BioFactors. 2008;21:197-201. https://doi.org/10.1002/biof.552210140

22. Dhar P, Kar CS, Ojha D, Pandey SK, Mitra J. Chemistry, phytotechnology, pharmacology and nutraceutical functions of kenaf (Hibiscus cannabinus L.) and roselle (Hibiscus sabdariffa L.) seed oil: An overview. Ind Crops Prod. 2015;77:323-32. https://doi.org/10.1016/j.indcrop.2015.08.064

23. Da-Costa-Rocha I, Bonnlaender B, Sievers H, Pischel I, Heinrich M. Hibiscus sabdariffa L. A phytochemical and pharmacological review. Food Chem. 2014;165:424-43. https://doi.org/10.1016/j.foodchem.2014.05.002

24. Vulić JJ, Tumbas VT, Savatović SM, Đilas SM, Ćetković GS, Čanadanović-Brunet JM. Polyphenolic content and antioxidant activity of the four berry fruits pomace extracts. Acta Period Technol. 2011;42:271-79. https://doi.org/10.2298/APT1142271V

25. Leonardis AD, Pizzella L, Macciola V. Evaluation of chlorogenic acid and its metabolites as potential antioxidants for fish oils. Eur J Lipid Sci Technol. 2008;110:941-48. https://doi.org/10.1002/ejlt.200700317 